\title{
PEMBELAJARAN BAHASA INDONESIA BERBASIS TEKS PADA SISWA KELAS XI SEKOLAH INTERNASIONAL BUKIT SION
}

\author{
Maryani* $^{*}$ \\ Handayani Sinaga** \\ *Sekolah Pascasarjana Uhamka Jakarta, Indonesia \\ * Sekolah Pascasarjana Uhamka Jakarta, Indonesia \\ *E-mail:maryanijuli@gmail.com \\ ${ }^{* *}$ E-mail: handayani_sinaga@gmail.com
}

\begin{abstract}
This study aims to describe the application of text-based learning to class XI students at Bukit Zion International School. The method used in this research is descriptive method. The informants in the study were Indonesian language teachers who taught in class XI and students. Data collection is done by analyzing the Learning Implementation Plan (RPP), observing its implementation and interview. The approach is carried out in the contex of online learning. The results showed a discrepancy between the time allocation contained in the lesson plans and the actual learning that had been carried out in class. After being confirmed, the teacher stated that the core activities lacked time so that the reviews given by the teacher after the students' presentations were not in-depth. This is because learning is done online.
\end{abstract}

Keywords: Indonesian language learning, text-based, foreign language students.

\begin{abstract}
Penelitian ini bertujuan untuk mendeskripsikan penerapan pembelajaran berbasis teks pada siswa kelas XI Sekolah Internasional Bukit Sion. Metode yang dipakai dalam penelitian ini yaitu metode deskriptif. Informan dalam penelitian yaitu guru Bahasa Indonesia yang mengajar di kelas XI dan siswa. Penggumpulan data dilakukan dengan menganalisis Rencana Pelaksanaan Pembelajaran (RPP), mengamati implementasinya dan wawancara. Penerapan pendekatan dilaknsaka dalam konteks pembelajaran daring. Hasil penelitian menunjukkan ketidaksesuaian antara alokasi waktu yang terdapat pada RPP dengan pembelajaran sebenarnya yang telah dilakukan di kelas. Setelah dikonformasi guru menyatakan bahwa pada kegiatan inti kekurangan waktu sehingga ulasan yang diberikan oleh guru setelah siswa presentasi kurang mendalam. Hal ini disebabkan karena pembelajaran dilakukan secara daring.
\end{abstract}

Kata kunci: pembelajaran Bahasa Indonesia, berbasis teks, siswa berbahasa asing. 


\section{PENDAHULUAN}

Pembelajaran bahasa Indonesia merupakan pembelajaran yang wajib ada di setiap jenjang Pendidikan sekolah. Pembelajaran Bahasa Indonesia dilakukan dengan maksud dan tujuan supaya para siswa mempunyai kompetensi berbahasa Indonesia yang dipakai dalam beraneka ragam keperluan. Hal ini mengisyaratkan siswa mempelajari serta melatih diri pada aneka macam genre yang selaras dengan tujuan aktivitas sosial dan tujuan komunikasi yang mempunyai kekhasan cara pengungkapan (struktur retorika teks) dan kekhasan kaidah kebahasaan. Untuk mencapai tujuan tersebut, siswa yang belajara Bahasa Indonesia berorientasi pada pembelajaran berbasis teks. Keselarasan pembelajaran berbasis teks akan mengintegrasikan penetahuan, keterampilan, dan sikap menjadi ciri khas pembelajaran bahasa Indonesia yang sekarang dengan pembelajaran bahasa Indonesia yang telah dilakukan sebelumnya (Saragih, 2016).

Muatan kurikulum mata pelajaran bahasa Indonesia khususnya bertujuan meningkatkan kemampuan siswa berkomunikasi dengan bahasa Indonesia secara baik dan benar serta menumbuhkan apresiasi terhadap hasil karya kesastraan siswa Indonesia. Pada pelaksanaannya pembelajaran bahasa Indonesia tidak bisa terlepas dari keberadaan kurikulum Pendidikan (Pinasti, Intan Indria; Rohmadi,
Mohammad; Rakmawati, 2018). Karena secara langsung keduanya saling berkaitan satu sama lain.

Pembelajaran Bahasa Indonesia merupakan mata pelajaran yang terdapat pada kurikulum pendidikan Indonesia. Muatan kurikulum mata pelajaran bahasa Indonesia khususnya bertujuan meningkatkan kemampuan siswa berkomunikasi dengan bahasa Indonesia secara baik dan benar serta menumbuhkan apresiasi terhadap hasil karya kesastraan siswa Indonesia.

Seiring dengan perkembangan waktu, Pendidikan di Indonesia terus memperbaiki kualitasnya. Termasuk mata pelajaran Bahasa Indonesia. Adanya perubahan kurikulum yang terjadi di Indoneisa yang semula menerapkan KTSP diubah menjadi kurikulum 2013 berpengaruh dalam sistem pembelajaran. Pembelajaran bahasa Indonesia dalam Kurikulum 2013 dirancang menggunakan berbasis teks.

Dalam kurikulum 2013, standar kompetensi pelajaran Bahasa Indonesia adalah kualifikasi kemampuan minimal siswa yang mendeskripsikan pengetahuan, keterampilan, dan sikap positif terhadap bahasa dan sastra Indonesia. Standar kompetensi ini adalah dasar bagi siswa untuk memahami dan merespon situasi lokal, regional, nasional dan global (Damsir, 2021).

Dalam konsep pembelajaran Bahasa Indonesia berbasis teks, teks bukan hanya diartikan sebatas tulisan 
namun teks adalah semacam aktivitas sosial yang mempunyai tujuan sosial (Kementerian

Pendidikan

dan Kebudayaan, 2017). Dengan demikian, segala pembelajaran Bahasa Indonesia harus mampu mengusung segala yang bermuatan dengan aktivitas sosial masyarakat.

Pembelajaran Berbasis Teks adalah pembelajaran yang berorientasi terhadap kemampuan siswa dipakai menyusun teks. Metode pembelajaran ini mendasarkan diri dalam pemodelan teks dan analisis terhadap fitur-fiturnya secara eksplisit dan penekanan interaksi antara teks dan konteks penggunaannya. Perancangan unit-unit pembelajarannya mengarahkan siswa supaya bisa tahu dan menghasilkan teks baik verbal juga tulis pada aneka macam konteks. Pembelajaran bahasa Indonesia berbasis teks dalam kurikulum 2013 merupakan bentuk kesadaran yang memiliki peranan penting sebagai wahana dalam mengekspresikan pikiran dan perasaan secaraindah dan logis (Ramadania, 2016).

Hal ini dipandang berdasarkan proses pembelajaran yang diawali dengan pengetahuan mengenai jenis teks, dilanjutkan kaidah kebahasaan, lalu keterampilan menyajikan suatu teks tulis dan lisan. Tujuan umum pendidikan dan pembelajaran Bahasa Indonesia pada jenjang Pendidikan adalah memantapkan kedudukan dan fungsi Bahasa Indonesia (Hidayat, 2001).
Pembelajaran secara general yaitu proses hubungan antara pendidik dan peserta didik juga antarpeserta didik lainnya (Fadlillah, 2014). Pembelajaran berbasis teks merupakan aktivitas belajar mengajar yang dilakukan sesuai dengan teks yang diajarkan. Pada pembelajaran berbasis teks pada kelas, siswa dituntut agar tahu setiap jenis teks lalu mendemonstrasi struktur isi dan bahasanya.

Pembelajaran berbasis teks mendorong pembelajar agar membaca dan membaca (Priyatni, 2014). Pada pembelajaran berbasis teks pada kelas, siswa dituntut untuk memahami setiap jenis teks lalu mendemonstrasi struktur isi dan bahasanya. Menyusun teks merupakan suatu aktivitas yang kompleks yang membutuhkan kegiatan yang teratur (sistematiss), terkontrol, empirik, dan kritis (Mahsun, 2014). Mata pelajaran Bahasa Indonesia pada Kurikulum 2013 yang menekankan pentingnya kompetensi sikap, pengetahuan, dan keterampilan, pada kemampuan berbahasa siswa dibentuk melalui pembelajaran berbasis teks secara berkelanjutan. Hal ini dipandang berdasarkan proses pembelajaran yang diawali menggunakan pengetahuan mengenai jenis teks, dilanjutkan menggunakan kaidah kebahasaan, lalu keterampilan menyajikan suatu teks tulis dan lisan. Selama proses pembelajaran ini berlangsung, pendidik dapat membangun pengetahuan, keterampilan, dan sikap anak didik. 
Konteks sosial serta konteks budaya pada kehidupan sosial mempunyai pengaruh satu sama lain terhadap keberagaman wujud teks. Implementasi Pembelajaran Bahasa Indonesia Berbasis Teks pada Sekolah Menengah Atas Bukit Sion Kelas XI bahwa keberagaman teks dengan struktur teks yang bervariasi juga dipakai untuk keperluannya tersendiri (Mahsun, 2014). Bahasa yang dipakai dengan tujuan sosial tertentu itulah yang melahirkan teks.

Teks bisa dikelompokkan dalam dua kategori besar (aliran), yaitu aliran sastra \& aliran faktual. Genre (aliran) sastra bertujuan guna mengajukan emosi dan imaji pembaca/penyimak. Genre sastra dikelompokkan dalam tiga jenis yaitu teks naratif (novel, cerpen), puitik, dan dramatik. Genre faktual menghadirkan informasi/ gagasan dan bertujuan agar menggambarkan, menceritakan, atau meyakinkan pembaca/penyimak (Priyatni, 2014). Teks merupakan proses sosial yang berorientasi dengan tujuan sosial eksklusif serta pada konteks situasi eksklusif pula (Priyatni, 2014). Setiap jenjang pendidikan mempunyai jenis teks dan tingkat kesukaran yang tidak selaras sesuai tingkatannya. Pada jenjang Sekolah Menengah Atas (SMA) yg dimuat Permendikbud No. 69 tahun 2013 (dalam (Priyatni, 2014)) masih ada 15 jenis teks. Hal penting pada tahapan pembelajaran jangan membawa siswa langsung mempelajari pembahasan model teks tanpa upaya menciptakan kondisi perantara. Pada tingkatan pertama aktivitas-aktivitas menciptakan konteks dengan menerapkan pengetahuan dasar terlebih dahulu pada siswa dan dilanjutkan dengan tingkatan pemodelan teks. Pendidik mengenalkan nilai, tujuan sosial, struktur, dan karakteristik bentuk, termasuk karakteristik kebahasaan yang sebagai penanda teks yang akan diajarkan.

Tahap selanjutnya merupakan kolaborasi menciptakan teks. Kegiatannya bisa meliputi aktivitas menciptakan nilai, sikap, dan keterampilan melalui teks yang utuh secara bersamasama. Tahap terakhir menciptakan teks secara mandiri. Aktivitas pembelajaran menjadi suatu sistem yang mempunyai bagian-bagian dan fungsi masing-masing agar mencapai tujuan pembelajaran yang sudah dirumuskan (Sutikno, 2009). Dengan begitu pentingnya bagi pendidik agar mampu menciptakan rancangan aktivitas pembelajaran supaya tujuan pembelajaran bisa tercapai.

Pembelajaran Bahasa Indonesia berbasis teks menjadi pilihan yang tepat sebagai penghela ilmu pengetahuan. Hal ini sangat relevan dengan kondisi saat ini. Pada saat ini para siswa sedang berada di era revolusi industri 4.0. Arus modernisasi dan perkembangan teknologi merasuk dalam segala sendi kehidupan masyarakat Indonesia tidak terkecuali para siswa. Siswa dengan mudah mengakses segala informasi 
secara cepat hanya dengan genggaman tangan.

Untuk itulah pembelajaran Bahasa Indonesia hadir sebagai penghela ilmu pengetahuan dan budaya Indonesia yaitu melalui pembelajaran berbasis teks. Salah satu hal permasalahan yang menarik untuk ditulis ialah bagaimana implementasi pembelajaran Bahasa Indonesia di sekolah internasional. Mengingat siswa yang belajar di sekolah internasional Sebagian besar ialah siswa yang beraneka ragam latar belakang sosial serta didominasi oleh siswa yang setiap harinya selalu menggunakan bahasa asing untuk berkomunikasi. Hal inilah yang menjadi daya Tarik tersendiri penulis untuk membahas implementasi pembelajaran Bahasa Indonesia pada sekolah internasional Bukit Sion.

Penelitian mengenai implementasi pembelajaran Bahasa Indonesia berbasis teks bukanlah penelitian yang pertama. Pada tahun 2019 telah terbit sebuah jurnal yang ditulis oleh Purnama Sari Vidya Dharma, Ria Ariesta, dan Agus Joko Purwadi Program Studi Pendidikan Bahasa Indonesia Jurusan Pendidikan Bahasa dan Seni FKIP Universitas Bengkulu. Penelitian tersebut berjudul Implementasi Pembelajaran Bahasa Indonesia Berbasis Teks di SMA Negeri 1 Bengkulu Tengah Kelas XI (Ariesta, R., Purwadi, A. J., \& Dharma, 2019).

Hasil penelitian menunjukkan perencanaan pembelajaran berbasis teks berdasarkan Rancangan Pelaksanaan
Pembelajaran yang ditulis pendidik telah menerangkan langkah pembelajaran berbasis teks menggunakan aktivitas pembelajaran. Hasil pelaksanaan pembelajaran berbasis teks memperlihatkan bahwa berdasarkan keempat tahapan pembelajaran berbasis teks, terdapat satu tahapan yang tidak dilaksanakan yaitu langkah mencipta teks secara mandiri. Alokasi waktu perencanaan pembelajaran kurang sesuai dengan alokasi saat pembelajaran berbasis teks. Jam belajar yang singkat dan adanya aktivitas sekolah berdampak dalam pembelajaran berbasis teks dilaksanakan kurang efektif. Hasil evaluasi pendidik terhadap siswa memperlihatkan selama proses implementasi pembelajaran berbasis teks yang dilakukan telah tercapai.

Penelitian yang telah dilakukan sebelumnya dangan penelitian ini memiliki persamaan dan perbedaan. Persamaan kedua penelitian ini ialah implementasi pembelajaran Bahasa Indonesia berbasis teks pada jenjang SMA. Namun ada perbedaan yang mencolok yaitu lokasi penelitian. Pada penelitian sebelumnya dilaksanakan pada sekolah negeri sedangkan penelitian ini dilaksanakan pada sekolah internasional Bukit Sion. Karakteristik siswa di Sekolah Internasional Bukit Sion didominasi oleh siswa keturunan luar negeri dan juga menggunakan Bahasa Asing untuk komunikasi menjadi keunikan tersendiri dalam penelitian ini. Maka 
rumusan masalah penelitian ini ialah bagaimana implementasi pembelajaran Bahasa Indonesia berbasis teks pada siswa kelas XI sekolah internasional Bukit Sion?

\section{METODE}

Penelitian ini memakai metode penelitian deskriptif kualitatif yang menggambarkan pembelajaran Bahasa Indonesia berbasis teks pada kelas XI Sekolah Internasional Bukit Sion tahun ajaran 2020/2021. Lokasi penelitian dilakukan di Sekolah internasional Bukit Sion yang beralamat di Taman Kebon Jeruk Intercon Blok GA1, Daerah Khusus Ibukota Jakarta. Waktu penelitian dilakukan saat semester genap tahun ajaran 2020/2021 bulan Mei. Data dalam penelitian ini berupa data observasi, rekaman, dokumentsi yang diambil dari RPP yang dipakai guru, kegiatan belajar dalam kelas, informasi yang diberikan guru, serta informasi dari dokumentsi yang penulis peroleh. Sumber data penelitian ini yaitu satu guru Bahasa Indonesia, siswa, serta dokumentasi. Teknik pengumpulan data yang dipakai yaitu Dokumentasi, wawancara, dan observasi. Data yang diperoleh berdasarkan hasil triangulasi data. Instrumen yang dipakai berupa lembar observasi menggunakan aspek perencanaan, pelaksanaan, dan alokasi waktu. Peneliti ini memakai validasi data melalui cara melakukan triangulasi sumber melalui wawancara kepada pendidik mata pelajaran Bahasa
Indonesia yang mengajar pada kelas XI. Pada saat penelitian, peneliti melakukan pengecekan data pada narasumber (guru) menggunakan cara peneliti melakukan wawancara kepada narasumber tentang data yang sudah peneliti peroleh sesuai dengan hasil observasi dan dokumentasi.

Peneliti yang berperan sebagai instrumen, berfungsi menjadi penetap titik penting penelitian, menentukan informan, melakukan pengumpulan data, melakukan analisis, menafsirkan data dan membuat kesimpulan. Kisikisi observasi yang dipakai pada penelitian ini diambil menurut aspek RPP berupa aspek perencanaan, pelaksanaan, pemodelan teks dan alokasi waktu.

Adapun langkah-langkah pengolahan data dalam penelitian ini. Pertama melakukan analisis catatan dan rubrik observasi. Kedua melakukan pengamatan dan pada dokumen RPP. Ketiga pengolahan hasil wawancara. Hasil pengolahan data tersebut kemudian dideskripsikan.

\section{HASIL DAN PEMBAHASAN Hasil Penelitian}

Pembelajaran Bahasa Indonesia di kelas XI Sekolah Internasional Bukit Sion dilaksanakan dengan berpedoman pada Rencana Pelaksanaan Pembelajaran (RPP). Pelaksanaan pembelajaran menggunakan teks dengan penerapkan pendekatan saintifik. Meskipun sekolah Internasional Bukit Sion para siswa 
didominasi oleh siswa keturunan asing namun pelaksanaan pembelajaran Bahasa Indonesia tetap mengikuti kurikulum pemerintah Indonesia yaitu K13.

Pembelajaran itu sendiri dapat dimaknai sebagai suatu proses interaksi guru dan siswa untuk mencapai tujuan pembelajaran. Langkah-langkah pembelajaran berbasis teks terdiri dari menciptakan konteks, pemodelan teks, mengkonstruksi teks secara bersama, dan menulis teks secara mandiri (Mahsun, 2014).

Pengajaran Bahasa Indonesia di kelas XI Sekolah Internasional Bukit Sion dilaksanakan berdasarkan RPP yang telah dibuat oleh guru. RPP disusun berdasarkan SK dan KD yang terdapat pada kurikulum 2013. Kegiatan pembelajaran dan materi ajar dilaksanakan dengan menyesuaikan kondisi pembelajaran di masa pandemi Covid-19. Mengingat sejak Maret 2020 sampai dengan sekarang Pendidikan di Indonesia masih menerapkan pembelajaran dalam jaringan (daring). Untuk itu pembelajaran dilaksanakan dengan menggunakan zoom dan Rencana Pelaksanaan Pembelajaran (RPP) menggunakan RPP darurat.

Rencana pembelajaran yang dilakukan oleh guru yaitu menyusun RPP, evaluasi, dan media pembelajaran berupa zoom. Berdasarkan hasil observasi yang telah dilakukan. Guru melakukan perencanaan pembelajaran berbasis teks dengan melakukan pembangunan konteks, pemodelan teks, pembuatan teks secara berkelompok, dan pembuatan teks secara mandiri oleh siswa.

Pelaksanaan pembelajaran yang telah direncanakan oleh guru kemudian diterapkan oleh guru dan siswa. Pembelajaran dilakukan dengan menggunakan media zoom. siswa dan guru melakukan pembelajaran dalam satu room zoom. Zoom dipilih oleh guru dengan pertimbangan kemudahan dan kelengkapan layanan yang ada pada zoom. Guru bisa memantau secara langsung kegiatan pembelajaran dan mempermudah siswa untuk tanya jawab secara langsung kepada guru. Dengan menggunakan zoom guru dan siswa bisa share screen power point bahkan juga video-video pembelajaran yang telah disiapkan oleh guru.

\section{Pembahasan Penelitian}

Pengajaran Bahasa Indonesia kelas XI Sekolah Internasional Bukit Sion dilaksanakan dengan berpatokan pada RPP. Pelaksanaan pembelajaran yang diamati ialah pembelajaran materi teks drama kelas XI. Sebelum pembelajaran dimulai pada setiap mata pelajaran selalu diawali dengan kegiatan membaca atau menonton video yang ditayangkan oleh guru. Kegiatan ini dilaksanakan selama 10 menit. Dalam satu materi teks drama dibagi menjadi empat pertemuan dengan empat RPP. Satu kali pertemuan dialokasikan selama $2 \times 40$ menit. Pertemuan pertama materi pokok ialah mengidentifikasi informasi yang terdapat pada teks 
drama. Pada tahap pendahuluan pembelajaran teks drama waktu yang dialokasikan sebanyak 10 menit.

Pembelajaran diawali dengan guru mengucapkan salam dan memandu siswa untuk berdoa. Selanjutnya guru menyapa murid sekaligus mengecek presensi siswa. Selanjutnya guru menyampaikan tujuan pembelajaran yang akan dicapai hari ini, melakukan apersepsi sekaligus motivasi, dan menyampaikan pokok materi, langkah pembelajaran, dan teknik penilaian.

Pada tahap pembukaan pembelajaran seperti yang tertulis di atas maka guru telah melaksanakan pembelajaran Bahasa Indonesia dengan membangun konteks. Hal ini terlihat pada saat guru menyampaikan tujuan pembelajaran, materi, Langkah pembelajaran, dan teknik penilaian. Guru membangun konteks dengan mengaitkan materi yang akan diajarkan dengan kejadian atau fenomena yang ada saat ini. Siswa diarahkan untuk mengidentifikasi permasalahan tersebut lalu guru meminta siswa menebak materi apa yang akan dipelajari hari ini berdasarkan permasalahan atau hal yang telah dikemukakan sebelumnya.

Pada tahap kedua yaitu kegiatan inti. Guru mengalokasikan waktu 60 menit. Kegiatan inti ini berisi tahapan pemodelan teks. Guru menayangkan teks drama pada layar zoom. Siswa diminta mengamati teks tersebut lalu siswa diminta mengajukan pertanyaan- pertanyaan. Dari pertanyaan tersebut siswa saling tanya jawab mengenai teks tersebut. Kemudian pada tahap ini siswa disajikan dua teks yaitu teks drama dan teks cerpen. Siswa diminta membedakan antara cerpen dan teks drama.

Setelah siswa dibimbing guru untuk menemukan poin-poin penting pada teks. Kemudian siswa Bersama guru membahas informasi yang terdapat pada teks. Siswa kemudian dipandu untuk menemukan fakta yang terdapat pada teks. Pada tahap ini juga siswa diberi evaluasi. Setelah mengerjakan evaluasi siswa dibantu untuk menemukan ciri-ciri teks berdasarkan hasil pekerjaannya.

Pada tahap akhir guru mengalokasikan 10 menit untuk melakukan kegiatan penutup. Pada bagian penutup ini siswa menyimpulkan pembelajaran hari ini. Siswa yang aktif diberi apresiasi oleh guru. Lalu guru menutup pembelajaran.

Pada pembelajaran ini guru telah melaksanakan tahapan untuk membangun konteks. Guru membangun konteks pembelajaran dengan cara mengaitkan pembelajaran dengan kejadian atau fenomena yang ada saat ini. Guru juga telah melakukan pemodelan teks dengan cara menayangkan teks pada layar zoom. Siswa diminta mengamati lalu siswa diminta membedakan teks drama dengan teks cerpen. 
Pada pertemuan kedua materi pokok yaitu struktur dan kaidah kebahasaan teks drama. Pelaksaan pembelajaran masih dilakukan secara daring dengan menggunakan aplikasi zoom. Sebelum pembelajaran atau disebut preclass siswa diajak menonton sebuah video pementasan drama. Kegiatan ini dilakukan selama 10 menit. Bertujuan untuk menarik minat siswa agar lebih siap untuk menerima pembelajaran Bahasa Indonesia hari ini.

Guru memulai pembelajaran pada tahap pendahuluan dengan alokasi waktu 10 menit. Kegiatan dibuka oleh guru dengan berdoa. Lalu guru dan siswa secara Bersama menyanyikan lagu nasional. Guru juga mengecek presensi siswa yang hadir dalam zoom. Untuk membangun konteks guru mengaitkan materi pembelajaran teks drama dengan pengalaman peserta didik. Guru juga memberikan gambaran mengenai manfaat mempelajari materi teks drama dalam kehidupan sehari-hari. Tahap ini juga guru memberikan motivasi belajar kepada siswa.

Setelah tahap pemdahuluan selesai guru melakukan inti pembelajaran. Alokasi waktu kegiatan inti ini selama 60 menit. Siswa diminta untuk mengamati teks drama yang terdapat pada buku teks halaman 240 . Pada tahap ini siswa mengidentifikasi teks dengan cara menjawab pertanyaan yang terdapat pada buku teks tersebut. Pertanyaan yang harus dijawab siswa terdiri dari 2 pertanyaan. Siswa menjawab pertanyaan perbedaan teks drama dengan teks cerpen. Kemudian siswa menjawab pertanyaan mengenai struktur atau bagian-bagian yang terdapat pada kedua teks yang ada pada buku teks halaman 240 .

Setelah siswa secara perseorangan mengidentifikasi struktur teks, Langkah selanjutnya yang dilakukan guru ialah siswa dibagi menjadi beberapa kelompok. Kelompok diberi lembar kerja. Lembar kerja berisi teks drama lalu kelompom diminta untuk mengumpulkan data/informasi mengenai struktur dan kebahasaan yang terdapat pada teks drama. Siswa diperkenankan memanfatakan informasi dari berbagai sumber. Pada kegiatan ini siswa secara berkelompok diarahkan untuk mengidentifikasi dan merumuskan permasalahan isi dan struktur serta alur dari teks tersebut. Pada tahap ini siswa megolah data yang diperoleh dalam bentuk bahan untuk presentasi.

Setelah data presentasi selesai dipersiapkan, satu persatu kelompok diminta untuk mempresentasikan hasil kerja kelompok melalui zoom. Kelompom lain menanggapi materi yang dipresentasikan. Pada tahap ini terjadi interaksi antara satu kelompok presentasi dengan kelompok lainnya. Pada tahap ini peranan guru ialah memberikan tanggapan dan memberikan ulasan atas materi yang telah dipresentasikan oleh kelompok.

Setelah kegiatan inti selesai, guru melakukan kegiatan penutup. Kegiatan 
penutup dilaksanakan dengan alokasi waktu 10 menit. Siswa diminta untuk membuat tulisan simpulanmateri yang telah dipelajari yaitu struktur dan kaidah kebahasaan teks drama pada buku tulis. Kemudian siswa dan guru melakukan refleksi dengan memberi komentar berkenanan pembelajaran yang telah dilakukan pada hari ini. Kemudian siswa diberi tugas oleh guru untuk membaca teks drama lainnya. Pada tahap ini juga guru menyampaikan rencana pembelajaran yang akan dilaksanakan pada pertemuan selanjutnya.

Pada pertemuan ketiga, guru memberikan pembelajaran materi mengkontruksi teks drama. Pertemuan diawali dengan kegiatan preclass. Preclass dilaksanakan selama 5 menit. Siswa diminta untuk menonton video pementasan drama singkat. Setelah kegiatan preclass selesai, guru mengawali kegiatan pembelajaran dengan kegiatan pembuka. Alokasi waktu yang tertera pada RPP untuk tahap pembukaan ini selama 10 menit. Kegiatan dibuka dengan membuka pembelajaran. Siswa dipandu untuk berdoa dan menyanyikan lagu nasional. Kemudian guru mendata kehadiran siswa. Guru memberi motivasi kepada siswa tentang manfaat pembelajaran teks drama dalam kehidupan. Kemudian guru menyampaikan materi dan langkah pembelajaran yang akan dilakukan.

Pada tahap inti waktu yang dialokasikan pada RPP selama 60 menit.
Kegiatan diawali dengan siswa dibagi menjadi beberapa kelompok. Kelompok diminta mengidentifikasi alur pada teks drama yang yang terdapat pada buku teks. Kemudian kelompok ditunjuk untuk mempresentasikan hasil kerjanya. Kelompok lain diminta untuk mengomentari hasil kerja yang telah dipresentasikan temannya. Pada tahap ini guru memberikan ulasan dan penguatan materi yang telah dipresentasikan kelompok.

Kemudian siswa secara mandiri diberi lembar kerja. Lembar kerja berisi teks cerpen lalu siswa diminta untuk membuat kerangka teks drama berdasarkan cerpen yang telah diberikan. Salah satu siswa ditunjuk guru untuk memaparkan rancangan (kerangka) teks drama yang akan ditulis. Siswa lainnya diminta untuk mengomentari. Guru memberikan komentar dan perbaikan.

Setelah kegiatan selesai, selanjutnya guru melaksanakan tahap penutup. Tahap ini dialokasikan selama 10 menit. Siswa diminta untuk menyimpulkan materi yang telah dipelajari hari ini. Kemudian siswa dan guru melakukan refleksi. Guru menyampaikan materi pembelajaran yang akan dilakukan pada pertemuan selanjutnya. Guru menutup pelajaran dan mengajak siswa berdoa.

Pada pertemuan keempat. Kegiatan diawali dengan preclass selama 5 menit. Siswa diminta untuk membaca satu buat teks drama. Setelah kegiatan preclass selesai, guru memulai 
pembelajaran tahap pembukaan. Alokasi waktu tahap ini selama 10 menit. Guru membuka kegiatan dengan menyapa murid, berdoa lalu menyanyikan lagu nasiona. Guru juga mengecek kehadiran siswa. Pada tahap ini juga guru mengulas sedikit pembelajaran yang telah dilaksanakan pada pertemuan sebelumnya. Guru menyampaikan kegiatan pembelajaran yang akan dilakukan pada hari ini. Guru memberi motivasi pada siswa.

Pada kegiatan inti alokasi waktu selama 40 menit. Siswa diminta untuk untuk mengembangkan kerangka teks drama yang telah disusun pada pembelajaran sebelumnya. Pada tahapan ini siswa menulis teks drama secara lengkap sesuai dengan kerangka yang telah dibuat. Guru menjadi fasilitator dengan memberikan bantuan atau menjawab pertanyaan bila ada siswa yang kesulitan dalam mengembangkan kerangka teks drama menjadi teks drama yang utuh. Setelah selesai, siswa diminta untuk memaparkan teks drama yang telah ditulis. Siswa lainnya diminta untuk memberikan komentar. Pada tahap ini juga secara Bersama siswa dibimbing untuk menyunting teks drama yang telah ditulis. Penyuntingan dilakukan tidak hanya sebatas kesalahan bahasa, ejaan, namun juga dari segi konten teks drama yang ditulis siswa.

Pada tahap penulisan ini membutuhkan waktu yang Panjang. Namun mengingat jam pelajaran hanya 2 jam mata pelajaran saja maka siswa yang mempresentasikan teks drama yang ditulis dibatasi satu siswa saja. Namun siswa lainnya diminta untuk melengkapi dan menyunting teks drama secara mandiri. Kegiatan ini dijadikan tugas rumah oleh guru.Hasil teks drama yang telah ditulis siswa ini akan diserahkan pada guru dengan menggunggah teks drama melalui google form.

Setelah guru selesai melaksanakan kegiatan inti dan melakukan pengarahan terkait tugas. Selanjutnya guru melaksanakan kegiatan penutup. Pada kegiatan penutup ini alokasi waktu 10 menit. Siswa diminta untuk menyimpulkan pembelajaran hari ini. Siswa diberi kesempatan untuk menanyakan materi yang belum dipahami. Guru menyampaikan materi yang akan dipelajari pada pertemuan selanjutnya. Kegiatan ditutup dengan doa dan guru mengucapkan salam penutup.

Berdasarkan hasil penelitian yang dipaparkan di atas menunjukkan bahwa pembelajaran Bahasa Indonesia kelas XI Sekolah Internasional Bukit Sion belum maksimal karena terkendala pada waktu. Hal ini disebabkan sekolah dilaksanakan secara daring sehingga kurang efektif dibanding dengan sekolah secara tatap muka. Kekurangan waktu ini terlihat saat siswa mempresentasikan hasil kerjanya tidak semua kelompok mempunyai kesempatan untuk mendapat giliran.

Untuk tahap-tahap pembelajaran Bahasa Indonesia berbasis teks sudah 
dilakukan secara berurutan dimulai dari membangun kontekk yaitu dengan mengaitkan materi ajar dengan kegiatan atau peristiwa yang ditemui oleh siswa di lingkungan sekitar. Kemudian tahap pemodelan teks dilaksanakan dengan baik. Guru menyajikan beberapa teks bahkan juga disajikan teks yang berbeda. Hal ini dilakukan supaya saat siswa mengidentifikasi teks tersebut siswa bisa membandingkan teks yang dipelajari dengan teks yang sejenis. Kegiatan pemodelan ini membuat siswa antusias dan berpikir kritis untuk menggali informasi yang terdapat pada teks.

Pada tahap mengkonstruksi teks telah dilaksanakan dengan baik. Siswa dipandu guru mengkonstruksi teks drama dengan menggunakan lembar kerja. Lembar kerja berisi teks cerpeb. Dari teks cerpen tersebut siswa membuat kerangka teks drama. Kemudian tahap menulis teks juga telah dilaksanakan dengan baik. Pada tahap ini siswa mengembangkan kerangka teks drama menjadi sebuah teks drama yang utuh. Agar menjadi teks drama yang baik, siswa mempresentasikan hasil kerjanya lalu diberi komentar oleh teman dan guru. Siswa secara Bersama menyunting teks agar teks yang dihasilkan sesuai dengan kaidah bahasa Indonesia dan memiliki konten teks drama yang bagus.

Berdasarkan hasil wawancara yang telah dilaksanakan pada guru pengampu mata pelajaran Bahasa Indonesia, pembelajaran sudah semaksimal mungkin dilaksanakan. Namun pada pelaksanaannya waktu 2 jam pelajaran masih kurang. Karena pembelajaran berbasis teks mendorong siswa untuk membaca teks sekaligus mengidentifikasi informasi yang ada pada teks. Kendala yang dialami guru ialah pembelajaran dengan menggunakan sistem daring di masa pandemi Covid-19 kurang efektif. Sebagian siswa kurang serius dalam belajar. selain itu, pembelajaran teks drama ini akan lebih menarik apabila teks yang telah ditulis siswa dipraktikkan oleh siswa di kelas. Namun mengingat situasi pandemi seperti ini siswa tidak bisa memperagakan teks drama tersebut.

\section{KESIMPULAN}

Pembelajaran berbasis teks pada siswa kelas XI Sekolah Internasional Bukit Sion telah dilaksanakan dengan baik. Guru dan siswa telah melaksanakan tahapan dengan berurutan. Namun ada beberapa kendala yang ditemukan karena faktor kondisi pembelajaran daring di masa pandemic Covid-19. Pembelajaran teks drama yang semestinya sangat menarik dengan mempraktikkan teks drama yang telah ditulis. Namun di masa pembelajaran daring ini siswa tidak bisa dipraktikkan karena situasi dan kondisi sehingga pembelajaran kurang menarik bagi siswa.

Berdasarkan temuan penelitian ada beberapa hal yang bisa diperbaiki dari pembelajaran berbasis teks yang 
dilaksanakan pada siswa kelas XI Sekolah Internasional Bukit Sion. Yang pertama ialah teks pembelajaran materi tata bahasa atau Kaidah Kebahasaan teks sebaiknay dilakukan terpisah dengan struktur teks. Hal ini karena pembelajaran kaidah bahasa teks sama saja sedang menitik beratkan materi pada tata bahasa Indoesia. Pada sekolah internasional yang Sebagian besar ialah siswa yang lebih lancar berbahasa Inggris dibanding dengan Bahasa Indonesia maka sebaiknya porsi pembelajaran kaidah kebahasaan teks lebih diperbanyak lagi.

\section{DAFTAR PUSTAKA}

Ariesta, R., Purwadi, A. J., \& Dharma, P. S. (2019). Implementasi Pembelajaran Bahasa Indonesia Berbasis Teks di SMA Negeri 1 Bengkulu Tengah Kelas XI. Jurnal Ilmiah Korpus, III(I).

Damsir, M. (2021). Meningkatkan Kemampuan Bercerita dalam Mata Pelajaran Bahasa Indonesia Siswa Kelas V SD Negeri 14 Banyu Asin III Melalui Media Gambar 2018/2019. Jurnal Lipnas, 2(2).

Fadlillah. (2014). Implementasi Kurikulum 2013. Ar-Ruzz Media.

Hidayat, K. (2001). Perencanaan Pengajaran Bahasa Indonesia. Trimitra Mandiri.

Kementerian Pendidikan dan Kebudayaan. (2017). Bahasa Indonesia SMP/MTs Kelas VII. Kemendikbud.

Mahsun. (2014). Teks dalam Pembelajaran Bahasa Indonesia. PT. Raja Grafindo Persada.

Pinasti, Intan Indria; Rohmadi, Mohammad; Rakmawati, dan A. (2018). Pembelajaran Bahasa Indonesia Berbasis Kurikulum 2013 (Studi Kasus Teks Ulasan Cerpen di Kelas VII SMP Negeri 2 Ngawi). Basastra Jurnal Penelitian Bahasa, Sastra Indonesia Dan Pengajarannya, 6(1).

Priyatni, E. T. (2014). Desain Pembelajaran Bahasa Indonesia dalam Kurikulum 2013. Bumi Aksara.

Ramadania, F. (2016). Konsep Bahasa Berbasis Teks pada Buku Ajar Kurikulum 2013. Stilistika: Jurnal Bahasa, Sastra, Dan Pengajarannya ISSN 2527-4104, 1(2).

Saragih, A. (2016). Pembelajaran Bahasa Berbasis Teks dalam Kurikulum 2013. Medan Makna, 14(2), 197-214.

Sutikno, S. (2009). Belajar dan Pembelajaran. Prospect. 